\title{
Heavy metal pollution load in sediment samples of the Buriganga river in Bangladesh
}

\author{
K. M. Mohiuddin*, M. M. Alam, Istiaq Ahmed and A. K. Chowdhury \\ Department of Agricultural Chemistry, Bangladesh Agricultural University, Mymensingh-2202, Bangladesh \\ *E-mail: mohiagchem@gmail.com
}

\begin{abstract}
A study was conducted to assess the level of $\mathrm{Cr}, \mathrm{Pb}, \mathrm{Cd}, \mathrm{Ni}, \mathrm{Zn}, \mathrm{Cu}, \mathrm{Fe}$ and $\mathrm{Mn}$ contamination in the sediment samples of the Buriganga river, at the Department of Agricultural Chemistry, Bangladesh Agricultural University, Mymensingh. Total 14 sediment samples were collected from different areas of upstream of the Buriganga river. The mean concentrations of total $\mathrm{Cr}, \mathrm{Pb}, \mathrm{Cd}, \mathrm{Ni}, \mathrm{Fe}, \mathrm{Cu}, \mathrm{Zn}$ and $\mathrm{Mn}$ in the sediment samples were 173.4, 31.4, 1.5, 153.3, 481.8, 344.2, 12989 and $4036 \mu \mathrm{g} \mathrm{g}^{-1}$, respectively. The range of $\mathrm{pH}$ and $\mathrm{EC}$ of sediment were 5.87-8.21 and 230-707 $\mu \mathrm{S} \mathrm{cm}^{-1}$, respectively. The mean value of organic matter in sediment samples was $13.4 \%$. Heavy metal concentrations in sediment were compared with geochemical background and standard values, previous report on the Buriganga river and other rivers in Bangladesh. The average concentration of $\mathrm{Cr}, \mathrm{Pb}$ and $\mathrm{Ni}$ in sediments of the Buriganga river is almost twice of the geochemical background i.e. average worldwide shale standard and continental upper crust value, $\mathrm{Cd}$ and $\mathrm{Zn}$ is about five times and $\mathrm{Cu}$ content is about ten times higher than the geochemical background values. Average concentration of $\mathrm{Cr}, \mathrm{Cu}$ and $\mathrm{Ni}$ exceeded the severe effect level (SEL) values, where as $\mathrm{Pb}, \mathrm{Cd}$ and $\mathrm{Zn}$ exceeded toxicity reference values (TRV). However, the concentration of heavy metal in the sediment samples of the Buriganga river for the year 2009 of the same river reported by corresponding author was relatively higher than this study average. The average Enrichment factors (EFc) for $\mathrm{Zn}, \mathrm{Cu}, \mathrm{Mn}$ and Cd reflects extremely contaminated pollution level which implies that these metals originated from point source of pollution and very severely enriched in river sediments. The pollution load index (PLI) of sediments of the studied region varied from 1.61-7.51. The geoaccumulation index $\left(I_{g e o}\right)$ for $\mathrm{Cu}$ of five locations was greater than 3.0, which exhibited strongly polluted sediment quality. The $I_{\text {geo }}$ for $\mathrm{Mn}$ in 11 locations and $\mathrm{Zn}$ in 12 sites were greater than 1.0, indicated moderately polluted sediment quality. Heavy metal pollution intensity in the Buriganga river water and sediments signaled alarming condition for city dwellers and aquatic ecosystem of the river. Sustainable steps and continuous monitoring on pollution prevention and cleanup operation is suggested to minimize pollution.
\end{abstract}

Keywords: Heavy metal, Sediments, Buriganga river, Pollution load

\section{Introduction}

Heavy metals are considered the most common environmental pollutants, and their occurrence in waters and biota indicate the presence of natural or anthropogenic sources. Heavy metals like $\mathrm{Cr}, \mathrm{Pb}, \mathrm{Cd}, \mathrm{As}$ etc. exhibit extreme toxicity even at trace levels. Rivers are a dominant pathway for metals transport (Miller et al., 2003) and heavy metals become significant pollutants of many riverine systems (Dassenakis et al., 1998). In the distant past, a course of the Ganges river used to reach the Bay of Bengal through the Dhaleshwari river. This course gradually shifted and ultimately lost its link with the main channel of the Ganges and was renamed as the Buriganga. The Buriganga is the main river flowing beside Dhaka, a megacity of 12 million people. City dwellers largely depend on the Buriganga river for cleaning utensils and other commodities, fishing and carrying merchandise. But unfortunately it is now considered as one of the dirtiest rivers. Intensive human intervention, unplanned urbanization and population pressure have created the present unwanted situation. Insensible human actions and failure of the authority to enforce rules and regulations, the Buriganga is to die biologically (Alam, 2008). No fish and other aquatic animals are found in the river during the dry season. The major reasons of pollution in the Buriganga are the 46 years old Hazaribagh tannery and no treatment plant has been introduced yet to neutralize the noxious materials it produces. The industrial and the seepage wastes of riverside textile mills, dying and other industries and Dhaka-Demra-Naraynganj industrial zone also pollute the river. The industries of Kamrangir Char area dump their wastes in the Buriganga. Dhaka Water Supply and Sewerage Authority is in lack of sufficient recycling plants and dump seepage wastes in river. More than 5 thousand tons of solid wastes are produced daily from domestic uses in Dhaka city and $63 \%$ of them are dumped in the river. 
Most of the previous studies mainly focused on the Buriganga river water chemistry (Moniruzzaman et al., 2009; Ahmad et al., 2010). Mohiuddin et al. (2011) collected water and sediment sample form the Buriganga river in 2009 and reported the seasonal and spatial distribution of heavy metals indicating extreme heavy metal pollution load in sediments. However in the mean time Govt. of Bangladesh has taken various steps to clean up the Buriganga river. In 2010, Bangladesh Inland Water Transport Authority (BIWTA) began extracting hundreds of thousands of tonnes of garbage from the Buriganga river that being slowly choked by waste, mostly non-biodegradable polythene bags. In June 2011, the High Court of Bangladesh directed the chairman of Dhaka Water Supply and Sewerage Authority (WASA) to take steps to seal off the waste outlets and asked the Dhaka City Corporation to immediately start cleaning the riverbanks to stop dumping any more waste into or by the river. In 2012, BIWTA completed a mega project namely 'Construction of port facilities in order to prevent unauthorized encroachment of the Buriganga river and its foreshore land'. To remove wastes from the Buriganga river, 'Deposited Polythene and Other Waste Removal from the Buriganga and Turag Rivers' project was implemented by BIWTA, in the year 2013. Considering the above facts, the present research study was planned to carry out to follow up assessment of the heavy metal pollution load in the sediment samples of the Buriganga river in Bangladesh.

\section{Materials and Methods}

Sampling: Sediment samples were collected from 14 sites of the Buriganga river in January 2014 (Table 1 and Fig. 1). At each point, composite sediment samples were collected using standard protocol (US EPA, 2001). The sample mass collected in each case was about $500 \mathrm{~g}$. Sub-samples of the material were oven dried at $45^{\circ} \mathrm{C}$ for $48 \mathrm{hrs}$ and ground using mortar and pestle. Then the samples were sieved with the help of a sieve (aperture $63 \mu \mathrm{m}$ ). The lower particle size fraction was homogenized by grinding in an agate mortar and stored in carefully marked glass bottles until chemical analyses were carried out.

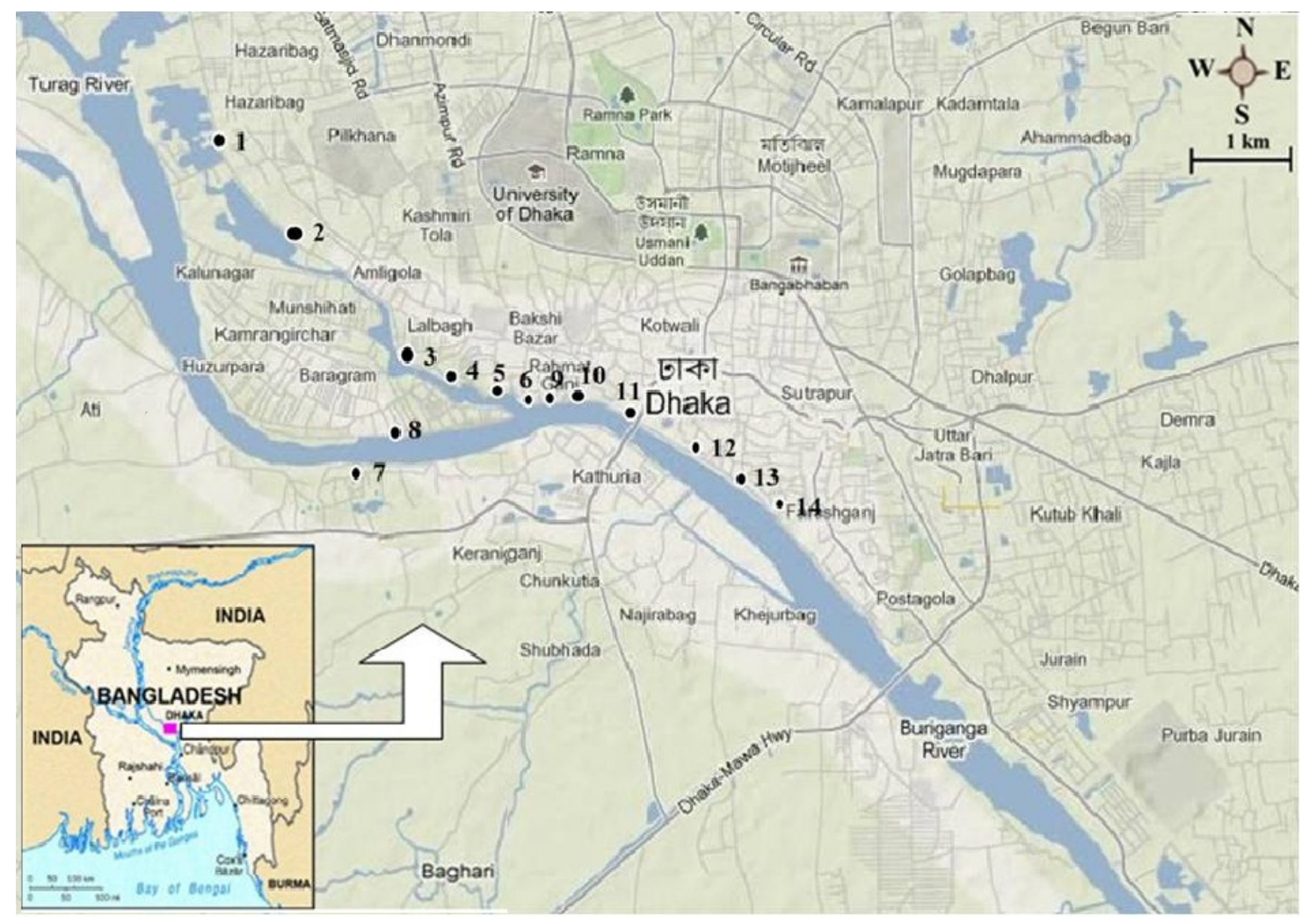

Fig. 1. Location of different sampling sites of the Buriganga River, Dhaka, Bangladesh 
Table 1. Name of the locations of different sampling sites of the river the Buriganga, Dhaka, Bangladesh

\begin{tabular}{c|lc|l}
\hline Sample No. & Location & Sample No. & Location \\
\hline 1 & Hazaribag - ZH Sikder MC & 8 & Kamrangirchor Tara Masjid \\
2 & Nobabgonj Bara Masjid & 9 & Swarighat \\
3 & Shohid Nagar Beribadh & 10 & Razar ghat \\
4 & Kellarmor Truck Stand & 11 & Badamtoli Bridge \\
5 & Islambag Alir ghat & 12 & Nowab Barir Ghat \\
6 & Raghunathpur & 13 & Sadar Ghat \\
7 & Borishur Lonch Terminal & 14 & Mererbag \\
\hline
\end{tabular}

Analysis of sediment samples: The $\mathrm{pH}$ of sediments was measured in 1:2.5 sediment to water ratio. The suspension was allowed to stand overnight prior to $\mathrm{pH}$ determination. $\mathrm{EC}$ was measured in saturation extract of sediments using EC meter. For the determination of total heavy metals, the extraction was carried out in Teflon containers provided with screw stoppers, using strong acid mixtures, as described by Tessier et al. (1979) and heavy metals concentrations in the extract were determined by Shimadzu Atomic Absorption Spectrophotometer (AA7000).

Enrichment factors (EFc): Enrichment factors $\left(E F_{c}\right)$ is considered as an effective tool to evaluate the magnitude of contaminants in the environment (Franco-Uria et al., 2009). The following equation was used to calculate the EFc:

$\mathrm{EFC}=\left(\mathrm{C}_{\mathrm{M}} / \mathrm{C}_{\mathrm{Fe}}\right)_{\text {sample }} /\left(\mathrm{C}_{\mathrm{M}} / \mathrm{C}_{\mathrm{Fe}}\right)_{\text {Earth's crust }}$

Where, $\left(\mathrm{C}_{\mathrm{M}} / \mathrm{C}_{\mathrm{Fe}}\right)_{\text {sample }}$ is the ratio of concentration of heavy metal $\left(\mathrm{C}_{\mathrm{M}}\right)$ to that of iron $\left(\mathrm{C}_{\mathrm{Fe}}\right)$ in the sediment sample, and $\left(\mathrm{C}_{\mathrm{M}} / \mathrm{C}_{\mathrm{Fe}}\right)_{\text {Earth's crust }}$ is the same reference ratio in the Earth's crust. Average shale values taken from Turekian and Wedepohl (1961).

Pollution load index (PLI): The pollution load index (PLI) proposed by Tomlinson et al., (1980) provides some understanding to the public of the area about the quantity of a component in the environment. The $\mathrm{PLI}$ of a single site is the $n$th root of $n$ number of multiplied together contamination factor (CF) values. The $\mathrm{CF}$ is the ratio obtained by dividing the concentration of each metal in the sediment by the baseline or background value.

$\mathrm{PLI}=\left(\mathrm{CF}_{1} \times \mathrm{CF}_{2} \times \mathrm{CF}_{3} \times \cdots \cdots \times \mathrm{CF}_{n}\right)^{1 / n}$

Site indices can be treated in exactly the same way to give a zone or area index. Therefore, PLI for a zone is the $n$th root of $n$ number of multiplied together PLI values. A PLI value of zero indicates perfection, a value of one indicates the presence of only baseline levels of pollutants, and values above one would indicate progressive deterioration of the site and estuarine quality (Tomlinson et al., 1980).

Table 2. Classification of sediments with regard to EF and $I_{\text {geo }}$ (Legorburu, 2013)

\begin{tabular}{c|ccll}
\hline Class & $I_{\text {geo }}$ & $E F$ & Pollution Level \\
\hline 0 & $<0$ & $<1.5$ & Unpolluted \\
1 & $0 \sim 1$ & $1.5 \sim 3$ & Unpolluted to moderately polluted \\
2 & $1 \sim 2$ & $3 \sim 6$ & Moderately polluted \\
3 & $2 \sim 3$ & $6 \sim 12$ & Moderately to strongly polluted \\
4 & $3 \sim 4$ & $12 \sim 24$ & Strongly polluted \\
5 & $4 \sim 5$ & $24 \sim 48$ & Strongly to extremely polluted \\
6 & $>5$ & $>48$ & Extremely polluted \\
\hline
\end{tabular}




\section{Index of Geoaccumulation (Igeo)}

The geoaccumulation index $\left(I_{g e o}\right)$ values were calculated after Muller (1969), which is

$$
I_{\text {geo }}=\log _{2}[C n /(1: 5 \times B n)]
$$

Where, $C_{n}$ is the measured concentration of element $\mathrm{n}$ in the sediment and $B_{n}$ is the geochemical background for the element $\mathrm{n}$ which is either directly measured in precivilization sediments of the area or taken from the literature (average shale value described by Turekian and Wedepohl, 1961). Based on EF and $I_{g e o}$, sediments can be categorized into seven classes (Table 2) (Legorburu et al. 2013).

\section{Results and Discussion}

\section{Physicochemical Properties of Sediments of the Buriganga River, Bangladesh}

The $\mathrm{pH}$ values of sediment samples were ranged from 5.87 to 8.21 (Table 3). The maximum pH 8.21 was recorded in sediment of Islambag Alirghat (Sample No. 05). The lowest pH value was observed 5.87 at Borishur Lonch Terminal (Sample No. 07). Various materials such as wastes, effluents, chemicals, salt etc. discharged from different industries might be responsible for such $\mathrm{pH}$ variation. Sediment $\mathrm{pH}$ has been identified as the key factor governing the concentration of soluble metals, which tends to increase at lower $\mathrm{pH}$ and decrease at higher $\mathrm{pH}$ (Wang and Qin, 2006). Thus acidic and alkaline nature of sediment of the study area may enhance toxic metal distribution and availability to plants. The EC of sediment samples collected from different locations of the Buriganga river is presented in Table 3. The EC of sediment samples ranged from 230 to $707 \mu \mathrm{S} \mathrm{cm}$. The highest EC $707 \mu \mathrm{S} \mathrm{cm} \mathrm{cm}^{-1}$ was obtained in sediments collected at Hazaribag - ZH Sikder MC (Sample No. 01). According to Costa et al. (2001), high EC in sediment, might be due to huge quantities of salt, solid wastes and effluents of tannery and other industries. In general, EC of sediment varied markedly with sediment salinity. The high salt affected soils of contaminated sites account for the higher EC. The low EC of uncontaminated sediment is related to comparatively low salinity hazards. The organic matter content in sediment collected from different sites of the Buriganga river has been presented in Table 3. The organic matter content ranged from 10.1 to $17.5 \%$. The highest organic carbon content (17.5\%) was obtained in the sediment collected from Swarighat (Sample No. 09). The deposition and decomposition of huge quantities of solid wastes and sewage sludge might be responsible for the organic matter enrichment in this sediment. From different studies, it was revealed that contaminated sediment contained relatively more organic matter than uncontaminated one. Organic matter along with clay contents of the soils had a significant influence on metal accumulation (Wang and Qin, 2006) and retention which could have implications on metal mobility and bioavailability (Manta et al., 2002; Zakir et al., 2008). Furthermore, the variations of organic matter might be due to fluctuation in temperature, rainfall, topography, soil textural class, soil pH and soil profile.

Table 3. Some physicochemical properties of sediment samples of different sites of the Buriganga river, Bangladesh

\begin{tabular}{|c|c|c|c|c|}
\hline Sample No. & $\mathrm{pH}$ & $\mathrm{EC}\left(\mu \mathrm{S} \mathrm{cm} \mathrm{cm}^{-1}\right)$ & $\%$ OC & $\% O M$ \\
\hline 1 & 7.45 & 707 & 5.9 & 10.1 \\
\hline 2 & 7.85 & 475 & 6.1 & 10.6 \\
\hline 3 & 7.15 & 370 & 7.9 & 13.7 \\
\hline 4 & 7.35 & 360 & 8.4 & 14.5 \\
\hline 5 & 8.21 & 496 & 8.7 & 15.0 \\
\hline 6 & 6.50 & 305 & 9.9 & 17.2 \\
\hline 7 & 5.87 & 540 & 7.0 & 12.1 \\
\hline 8 & 7.99 & 665 & 6.4 & 11.1 \\
\hline 9 & 7.05 & 230 & 10.1 & 17.5 \\
\hline 10 & 7.75 & 534 & 5.9 & 10.3 \\
\hline 11 & 7.90 & 372 & 9.4 & 16.2 \\
\hline 12 & 7.92 & 414 & 6.5 & 11.3 \\
\hline 13 & 7.63 & 595 & 8.3 & 14.3 \\
\hline 14 & 7.73 & 594 & 7.6 & 13.2 \\
\hline Range & $5.87-8.21$ & $230-707$ & $5.9-10.1$ & $10.1-17.5$ \\
\hline Mean & 7.45 & 475.5 & 7.7 & 13.4 \\
\hline
\end{tabular}




\section{Heavy metals in sediments collected from different areas of the Buriganga river}

The concentration of $\mathrm{Cr}$ in sediment samples ranged from 106.9 to $279.8 \mu \mathrm{g} \mathrm{g}^{-1}$ with a mean value of $173.4 \mathrm{\mu g} \mathrm{g}^{-1}$ (Table 4). Maximum concentration of $\mathrm{Cr}$ was found in sample No. 05 which was located in Islambag Alir ghat. The $\mathrm{Cr}$ concentration is also very high in other sites of the Buriganga river. The untreated $\mathrm{Cr}$ containing huge leather tanning wastes mix with the river water might results in the high $\mathrm{Cr}$ concentration. The $\mathrm{Cr}$ concentration is very high in all the sampling points located in the branch of the Buriganga, but the trend was decreasing towards the downstream sites (Mohiuddin et al. 2010). The $\mathrm{Cr}$ concentrations in sediment samples exceed this limit, indicating pollution. Chromium compounds are used as pigments, mordents and dyes in the textiles and as the tanning agent in leather. Anthropogenic sources of emission of $\mathrm{Cr}$ in the surface waters are from municipal wastes, laundry chemicals, paints, leather, road run off due to tire wear, brake wires, radiators (Dixit and Tiwari, 2008). Chromium in the Buriganga river most likely originated from the tanning process (Bhuiyan et al., 2010). The status of $\mathrm{Pb}$ in sediments ranged from 13.1 to $85.6 \mu \mathrm{g} \mathrm{g}^{-1}$, having an average value of $31.4 \mu \mathrm{g} \mathrm{g}^{-1}$ (Table 4). The permissible limit for $\mathrm{Pb}$ according to Dutch Standards is $85 \mu \mathrm{g} \mathrm{g}^{-1}$. Out of 14 samples three samples collected from the study areas were higher than maximum acceptable concentration of $50 \mu \mathrm{g} \mathrm{g}^{-1}$ for crop production (Kabata and Pendias, 1992). The status of $\mathrm{Cd}$ in sediments ranged from 0.47 to $7.02 \mu \mathrm{g} \mathrm{g}^{-1}$, having an average value of $1.5 \mathrm{\mu g} \mathrm{g}^{-1}$ (Table 4). The highest $\mathrm{Cd}$ was found at sample no. 6 and lowest at sample no. $12 \& 13$. Mohiuddin et al. (2011) was found Cd content ranged from 3.5-7.8 $\mu \mathrm{g} \mathrm{g}^{-1}$ in summer and 4.1-9.5 $\mathrm{g} \mathrm{g} \mathrm{g}^{-1}$ in winter. Swarighat (sample no. 9), the oldest and one of the main wholesale fish markets of the Dhaka city is situated in the high Cd containing area. The sediment concentration of nickel was found in the range of 79.5-278.4 $\mathrm{g} \mathrm{g} \mathrm{g}^{-1}$, with a mean value of $153.3 \mu \mathrm{g} \mathrm{g}^{-1}$ (Table 4). The highest sediment concentration of Ni was found at sample No. 14. The lowest sediment concentration of Ni was found at sample No. 1. The analysis of $\mathrm{Ni}$ showed that all the sample sites have concentration of $\mathrm{Ni}$ higher than the permissible limit and there is a need of remediation.

Table 4. Concentration of heavy metals in sediment samples collected from different sites of the Buriganga river, Bangladesh

\begin{tabular}{|c|c|c|c|c|c|c|c|c|}
\hline \multirow{2}{*}{ Sample No. } & \multicolumn{8}{|c|}{ Heavy metal concentration $\left(\mu \mathrm{g} \mathrm{g}^{-1}\right.$ ) } \\
\hline & $\mathrm{Cr}$ & $\mathbf{P b}$ & Cd & $\mathrm{Ni}$ & Zn & $\mathrm{Cu}$ & $\mathrm{Fe}$ & Mn \\
\hline 1 & 196.5 & 13.1 & 0.7 & 79.5 & 148.4 & 144.9 & 12475 & 2727 \\
\hline 2 & 110.3 & 18.3 & 1.3 & 96.6 & 473.0 & 141.8 & 13478 & 4578 \\
\hline 3 & 269.1 & 24.6 & 1.8 & 243.2 & 557.8 & 225.6 & 13027 & 3452 \\
\hline 4 & 106.9 & 51.2 & 1.2 & 159.1 & 801.9 & 648.0 & 13067 & 7409 \\
\hline 5 & 279.8 & 13.6 & 0.6 & 119.3 & 300.0 & 650.3 & 12353 & 4338 \\
\hline 6 & 187.2 & 85.6 & 7.0 & 221.6 & 803.8 & 609.2 & 14129 & 6393 \\
\hline 7 & 198.2 & 14.1 & 1.0 & 130.7 & 397.5 & 115.5 & 13031 & 2257 \\
\hline 8 & 137.3 & 52.7 & 0.8 & 126.5 & 721.1 & 565.7 & 13088 & 3622 \\
\hline 9 & 275.1 & 16.7 & 0.8 & 128.5 & 413.1 & 419.3 & 13722 & 3157 \\
\hline 10 & 130.5 & 38.7 & 1.2 & 96.6 & 539.8 & 560.9 & 12907 & 3732 \\
\hline 11 & 108.4 & 23.5 & 1.2 & 233.0 & 480.0 & 336.9 & 11943 & 3672 \\
\hline 12 & 114.5 & 22.0 & 0.5 & 85.2 & 238.7 & 88.3 & 12636 & 3777 \\
\hline 13 & 126.1 & 25.1 & 0.5 & 147.7 & 317.3 & 140.0 & 12842 & 4193 \\
\hline 14 & 187.3 & 40.7 & 2.9 & 278.4 & 552.7 & 172.0 & 13144 & 3197 \\
\hline Mean & 173.4 & 31.4 & 1.5 & 153.3 & 481.8 & 344.2 & 12989 & 4036 \\
\hline Range & $\begin{array}{l}106.9- \\
279.8\end{array}$ & $\begin{array}{l}13.1- \\
85.6\end{array}$ & $\begin{array}{l}0.5- \\
7.0\end{array}$ & $\begin{array}{l}79.5- \\
278.4\end{array}$ & $\begin{array}{c}148.4- \\
803.8\end{array}$ & $\begin{array}{l}88.3- \\
650.3\end{array}$ & $\begin{array}{c}11943- \\
14129\end{array}$ & $\begin{array}{c}2257- \\
7409\end{array}$ \\
\hline
\end{tabular}

The concentration of $\mathrm{Cu}$ in sediments ranged from 88.3 to $650.3 \mu \mathrm{g} \mathrm{g}^{-1}$, having an average value of 344.2 $\mu \mathrm{g} \mathrm{g}^{-1}$ (Table 4). Out of 14 sediment samples, only 01 sample had less than the maximum acceptable concentration $\left(100 \mu \mathrm{g} \mathrm{g}^{-1}\right)$ for crop production as reported by Kabata and Pendias (1992). The results of the present study were several times higher than those obtained in the earlier study of Domingo and Kyuma (1983) who reported that the Cu status of selected Bangladesh paddy soils ranged from 6.0 to $48.0 \mu \mathrm{g} \mathrm{g}^{-1}$. Zinc is one of the important trace elements that play a vital role in the physiological and metabolic process of many organisms. The total concentration of $\mathrm{Zn}$ in sediments ranged from 148.4 to $803.8 \mu \mathrm{g} \mathrm{g}^{-1}$, having an average value of $481.8 \mu \mathrm{g} \mathrm{g}^{-1}$ (Table 4). The Zn concentration of the present study 
is higher than those of the earlier study of Domingo and Kyuma (1983) who reported that the Bangladesh soils had a 10-110 $\mu \mathrm{g} \mathrm{Zn} \mathrm{g}^{-1}$, with a mean of $68 \mu \mathrm{g} \mathrm{g}^{-1}$. Iron comes into water from natural geological sources, industrial wastes, domestic discharge and also from by products. Excess amount of iron (more than $10 \mu \mathrm{g} \mathrm{g}^{-1}$ ) causes rapid increase in pulse rate and coagulation of blood in blood vessels, hypertension and drowsiness. The total concentration of Fe in sediments ranged from 11942.5 to 14129.3 $\mu \mathrm{g} \mathrm{g}{ }^{-1}$, having an average value of $12988.7 \mathrm{\mu g} \mathrm{g}^{-1}$ (Table 4). The concentration of $\mathrm{Mn}$ in sediments samples ranged from 2257 to $7409 \mu \mathrm{g} \mathrm{g}^{-1}$, with a mean value of $4036 \mu \mathrm{g} \mathrm{g}$ (Table 4). Out of 14 samples 05 samples exceed the mean value. Maximum Mn concentration was found in sample No. 04 which was located at Kellarmore Truck stand. The Mn concentration is also very high in other sites of the Buriganga river. All samples collected from the Buriganga river contained higher amount of $\mathrm{Mn}$. This is due to high amount of heavy metal present in river water. Manganese compounds are used in fertilizers, varnish and fungicides and as livestock feeding supplements.

Comparative analysis with Geochemical background and Standard values, Previous report on the Buriganga River and other Rivers in Bangladesh: The available data for a comparative analysis with geochemical background and standard values, previous report on the Buriganga river and Other rivers in Bangladesh, along with average values obtained for trace metals of the Buriganga river sediments are summarized in Table 5. It is evident that the average concentration of $\mathrm{Cr}, \mathrm{Pb}, \mathrm{Cd}, \mathrm{Zn}$ and $\mathrm{Cu}$ in sediments of the Buriganga river exceeded the geochemical background i.e. average worldwide shale standard and upper continental crust value, but the average concentration of $\mathrm{Pb}$ is very close to the geochemical standard values as well as toxicity reference values. The mean concentrations of total trace metals in sediments of the Buriganga river were several times higher than those of the other river sediments like Turag, Padma and Korotoa river. However, the concentration of heavy metal in the sediment sample for the year 2009 of the same river presented by Mohiuddin et al. (2011) is much higher than this study average (Table 5). This indicates that different initiatives taken by the Govt. of Bangladesh has distinct impact on the reduced content of heavy metal in the Buriganmga river sediment. But, till long way to go.

Table 5. Comparison of trace metal concentration $\left(\mu \mathrm{g} \mathrm{g}^{-1}\right)$ in the Buriganga River sediment samples with different standard values and Bangladeshi Rivers

\begin{tabular}{|c|c|c|c|c|c|c|c|c|c|c|}
\hline \multirow{2}{*}{$\begin{array}{l}\text { Heavy } \\
\text { metals }\end{array}$} & \multirow[t]{2}{*}{$\begin{array}{l}\text { This study } \\
\text { (average) }\end{array}$} & \multicolumn{4}{|c|}{$\begin{array}{l}\text { Geochemical background and } \\
\text { Standard values }\end{array}$} & \multicolumn{2}{|c|}{$\begin{array}{l}\text { Previous report on } \\
\text { Buriganga River }^{\mathrm{e}}\end{array}$} & \multicolumn{3}{|c|}{ Other Bangladeshi Rivers } \\
\hline & & $\mathrm{ASV}^{\mathrm{a}}$ & $C U C^{b}$ & $T^{T R V^{c}}$ & $\mathrm{SEL}^{\mathrm{d}}$ & Summer & Winter & Turag & Padma $^{g}$ & Korotoa $^{\mathrm{g}}$ \\
\hline $\mathrm{Cr}$ & 173.4 & 90 & 92 & 26 & 110 & 511 & 709 & 97 & 97 & 109 \\
\hline $\mathrm{Pb}$ & 31.4 & 20 & 17 & 31 & 250 & 475 & 478 & 24 & 17 & 58 \\
\hline $\mathrm{Cd}$ & 1.5 & 0.30 & 0.09 & 0.60 & 10 & 4.7 & 5.9 & - & - & 1.2 \\
\hline $\mathrm{Zn}$ & 481.8 & 95 & 67 & 110 & 820 & 713 & 958 & 111 & 76 & - \\
\hline $\mathrm{Cu}$ & 344.2 & 45 & 28 & 16 & 110 & 238 & 225 & 49 & 25 & 76 \\
\hline $\mathrm{Ni}$ & 153.3 & 68 & 47 & 16 & 75 & 113 & 137 & 42 & 28 & 95 \\
\hline
\end{tabular}

Note:

$\mathrm{ASV}=$ Average Shale value; $\mathrm{CUC}=$ Continental upper crust; $\mathrm{TRV}=$ Toxicity reference value; $\mathrm{SEL}=$ Severe effect level

${ }^{\mathrm{a}}$ Turekian and Wedepohl (1961)

${ }^{\mathrm{b}}$ Rudnick and Gao (2003)

${ }^{c}$ US EPA (1999)

${ }^{d}$ Persuad et al., (1993)

${ }^{\mathrm{e}}$ Mohiuddin et al. (2011)

'Zakir et al., (2006) and

${ }^{9}$ Datta and Subramanian (1998)

' Islam et al., (2015)

\section{Assessments of anthropogenic pollution in sediments}

Enrichment factors (EFc): It is presumed that high EFc values indicate an anthropogenic source of trace metals, mainly from activities such as industrialization, urbanization, deposition of industrial wastes and others. Since, the bioavailability and toxicity of any trace metals in sediments depend upon the chemical form and concentration of the metals (Kwon et al., 2001). Figure 2 represents the EFc values of all the 
toxic metals measured in the sediment of the Buriganga river. It is evident from the Fig. 2 that all the sampling sites had EFc values $>6.0$ for $\mathrm{Mn}$ and $\mathrm{Cu}$, indicating moderately to extremely polluted. Zinc and $\mathrm{Cd}$ also lies between moderately to extremely polluted except sampling location 1 for $\mathrm{Zn}$ and sampling location 12 for $\mathrm{Cd}$ exist in moderately polluted category. On the other hand, $\mathrm{Fe}$ in all the 14 locations exhibit as unpolluted (<1.5) (Fig. 2). The average EFC for $\mathrm{Zn}, \mathrm{Cu}, \mathrm{Mn}$ and $\mathrm{Cd}$ reflects extremely polluted pollution level which implies that these metals originated from point source of pollution and very severely enriched in river sediments. Bhuiyan et al., 2015 reported that $\mathrm{Cr}$, As, $\mathrm{Pb}$, and $\mathrm{Cd}$ were heavily enriched in sediments of the Buriganga river.

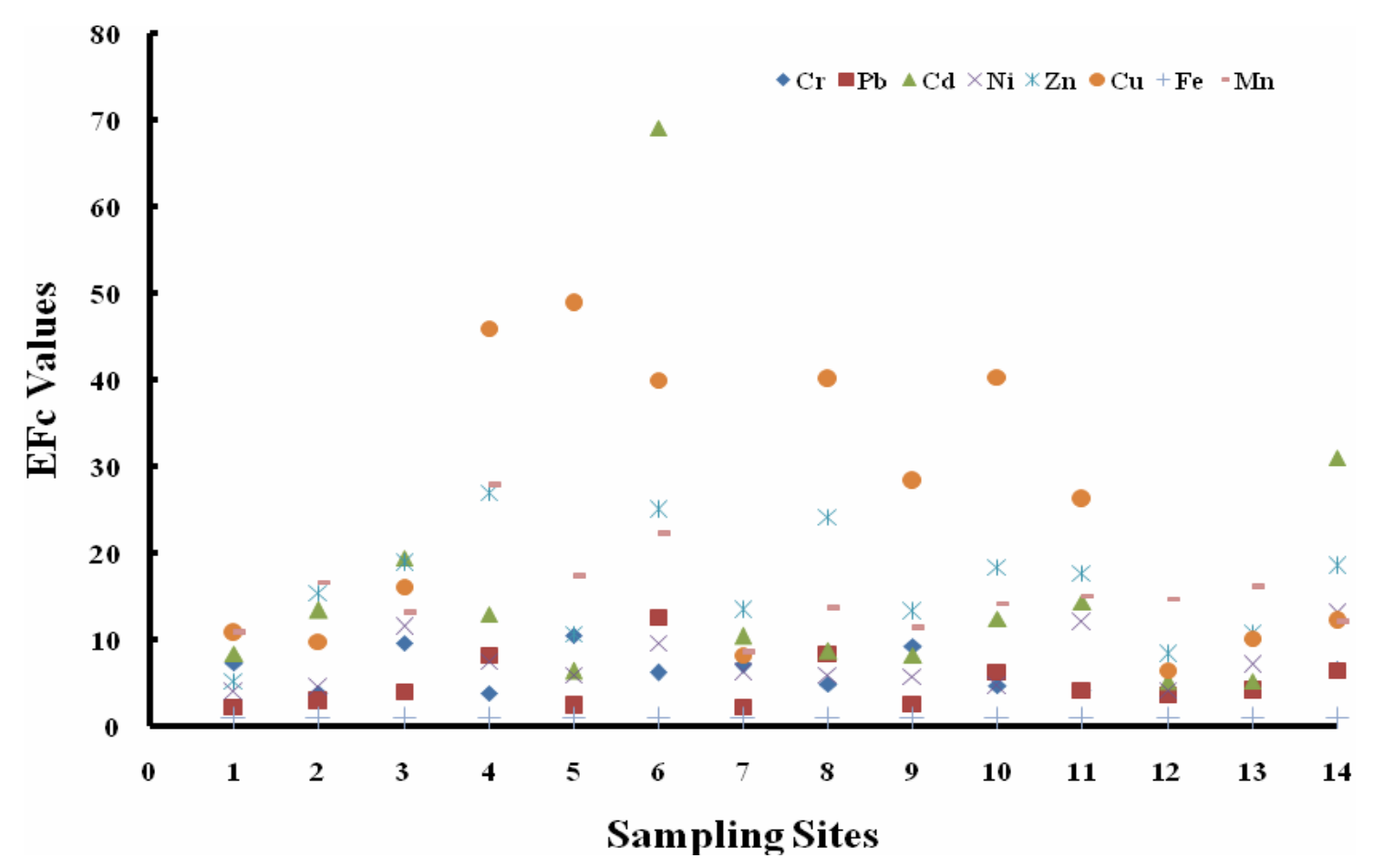

Fig. 2. Enrichment factor $(E F c)$ values of different sampling sites of the Buriganga river

\section{Pollution Load Index (PLI)}

The pollution load index (PLI) values of sediments of the studied region varied from site to site which ranged from 1.61-7.51 (Fig. 3). The Fig. 3 reflects the highest PLI values at Raghunathpur area of the Buriganga River. Second PLI value was found at Kellarmor Truck Stand. The area load is also higher (ALI 4.54). Chromium, $\mathrm{Cd}, \mathrm{Pb}, \mathrm{Zn}$, and $\mathrm{Cu}$ were the major pollutants contributing towards the higher PLI for the Buriganga river. Mohiuddin et al., (2011) reported that PLI values for summer and winter samples of the Buriganga river ranged from 4.9-24.2 and 5.2-27.4, respectively. This indicated the positive response in reducing the pollution load in the Buriganga river sediment from 2009 to 2014. 


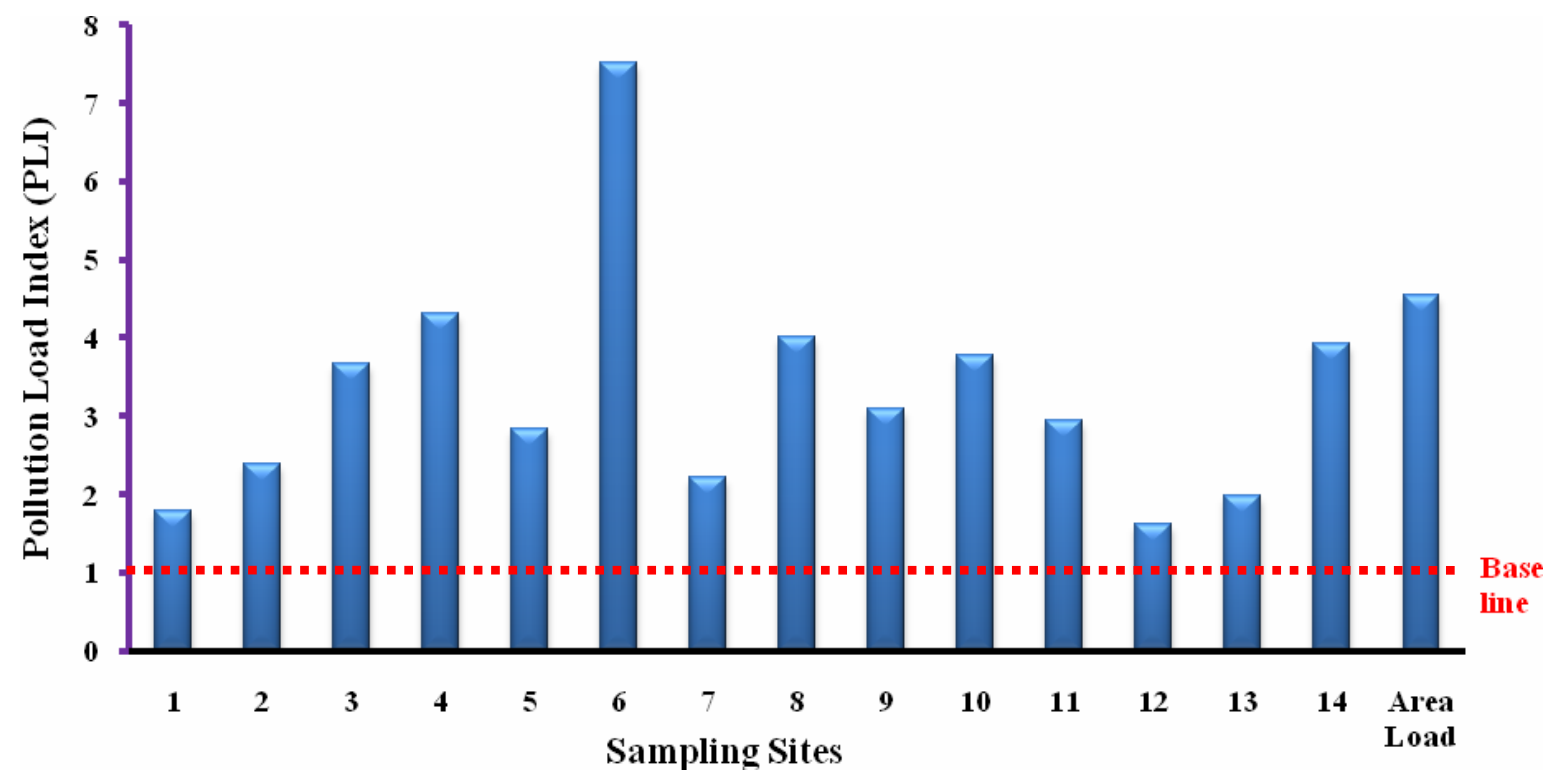

Fig. 3. Pollution load index (PLI) values of different sampling sites of the Buriganga river

\section{Index of Geoaccumulation ( $\left.I_{\text {geo }}\right)$}

The geoaccumulation index, $I_{\text {geo }}$ introduced by Muller (1969) was used to assess toxic metals pollution in sediments of the Buriganga river. The geoaccumuation index, includes seven grades (Table 2). The calculated $I_{\text {geo }}$ for toxic metals of sediments collected from different areas of the Buriganga river, and their corresponding contamination intensity are illustrated in Fig. 4 . While considering the $I_{\text {geo }}$ the values for $\mathrm{Pb}$, $\mathrm{Cr}$ and $\mathrm{Ni}$ river exhibited negative values $\left(I_{\text {geo }}<0\right)$ in most sampling locatins, that means $I_{\text {geo }}$ class: 0 , indicating unpolluted sediment quality. On the other hand, the $I_{\text {geo }}$ values for $\mathrm{Cu}$ of five locations were positive ( $\left.I_{g e o}>3\right)$, which also exhibited Igeo class: 4, indicating strongly polluted sediment quality (Fig. 4). The geoaccumuation index values for Mn of 11 locations were $>1.0$, which also exhibited $I_{\text {geo }}$ class: 2 , indicating moderately polluted sediment quality (Fig. 4). Similarly, In case of Zn, out of 14 locations, 12 sites exhibited positive values $\left(I_{\text {geo }}>1\right)$, that means $I_{\text {geo }}$ class 2 , indicating moderately polluted sediment quality.

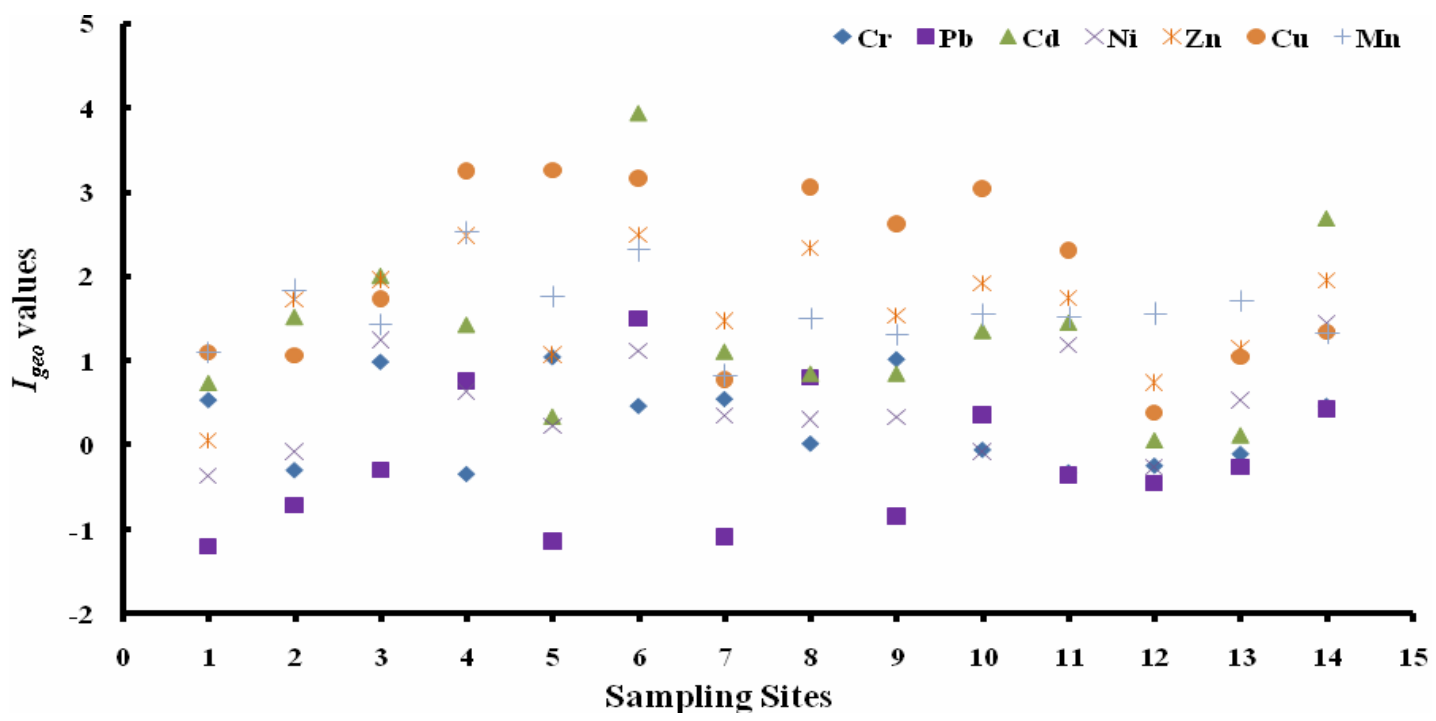

Fig. 4. Geoaccumulation index $\left(I_{\text {geo }}\right)$ values of different sampling sites of the Buriganga river 


\section{Conclusion}

All the sampling sites of the Buriganga river had EFc values $>6.0$ for $\mathrm{Mn}$ and $\mathrm{Cu}$, indicating moderately to extremely polluted. Zinc and $\mathrm{Cd}$ also lies between moderately to extremely polluted except in sampling location 01 (Hazaribag- ZH Sikder MC) for Zn and sampling location 12 (Nowab Barir Ghat) for Cd exist in moderately polluted category. The average EFc value implies that heavy metals in the Buriganga river sediments is severely enriched and mostly originated from the point source of pollution. The PLI values of all the sediment samples of the studied region also exceed the base line. Chromium, $\mathrm{Cd}, \mathrm{Pb}, \mathrm{Zn}$, and $\mathrm{Cu}$ were the major pollutants contributing towards the higher PLI for the Buriganga river.

\section{References}

Ahmad, M.K., Islam, S., Rahman, S., Haque, M.R. and Islam, M.M. 2010. Heavy Metals in Water, Sediment and Some Fishes of Buriganga River, Bangladesh. Int. J. Environ. Res. 4(2): 321-332.

Alam, K. 2008. Cost-Benefit Analysis of Restoring Buriganga River, Bangladesh. Water Resources Development. 24(4): 593-607.

Bhuiyan, M.A.H., Suruvi, N.I., Dampare, S.B., Islam, M.A., Quraishi, S.B., Ganyaglo, S. and Suzuki, S. 2010. Investigation of the possible sources of heavy metal contamination in lagoon and canal water in the tannery industrial area in Dhaka, Bangladesh. Environ. Monit. Assess. 175: 633-649.

Bhuiyan, M.A.H., Dampare, S.B., Islam, M.A. and Suzuki, S. 2015. Source apportionment and pollution evaluation of heavy metals in water and sediments of Buriganga River, Bangladesh, using multivariate analysis and pollution evaluation indices. Environ. Monit. Assess. 187: 4075.

Costa, C.N., Castilhos, D.D., Castilhos, R.M.V., Konrad, E.E., Passianoto, C.C. and Rodrigues, C.G. 2001. Tannery sludge effects on soil chemical properties, matter yield and nutrients uptake by soybean. Revista Brasileira de Agrociencia. 7(3): 189191.

Dassenakis, M., Scoullos, M., Foufa, E., Krasakopoulou, E., Pavlidou, A. and Kloukiniotou, M. 1998. Effects of multiple source pollution on a small Mediterranean river. Appl. Geochem. 13(2): 197-211.

Datta, D.K. and Subramanian, V. 1998. Distribution and fractionation of heavy metals in the surface sediments of the GangesBrahmaputra-Meghna river system in the Bengal basin. Environ. Geol. 36(1-2): 93-101.

Dixit, S. and Tiwari, S. 2008. Impact Assessment of Heavy Metal Pollution of Shahpura Lake, Bhopal, India. Int. J. Environ. Res. 2(1): 37-42.

Domingo, L.E. and Kyuma, K.1983. Trace elements in tropical assian paddy soils. I. Total trace element status. Soil Sci. Plant Nutri. 29(4): 439-452.

Franco-Uria, A., Lopez-Mateo, C., Roca, E. and Fernandez-Marcos, M.L. 2009. Source identification of heavy metals in pasture land by multivariate analysis in NW Spain. J. Hazard. Mater. 1651: 8-15.

Islam, M.S., Ahmed, M.K., Raknuzzaman, M., Al-Mamun, M.H. and Islam, M.K. 2015. Heavy metal pollution in surface water and sediment: A preliminary assessment of an urban river in a developing country. Ecol. Indicat. 48: 282-291.

Kabata, P.A. and Pendias, H. 1992. Trace Elements in Soils and Plants. $2^{\text {nd }}$ ed., CRC Press, London.

Kwon, Y.T., Lee, C.W. and Ahn, B.Y. 2001. Sedimentation pattern and sediments bioavailability in a wastewater discharging area by sequential metal analysis. Microchem. J. 68(2-3): 135-141.

Legorburu, I., Rodríguez, J.G., Borja, Á., Menchaca, I., Solaun, O., Valencia, V., Galparsoro, I. and Larreta, J. 2013. Source characterization and spatio-temporal evolution of the metal pollution in the sediments of the Basque estuaries (Bay of Biscay). Marine Pollution Bullet. 66(1-2): 25-38.

Manta, D.S., Angelone, M., Bellanca, A., Neri, R. and Sprovieri, M. 2002. Heavy metals in urban soils: A case study from the city of Palermo (Sicily), Italy. Sci. Total Environ. 300: 229-243.

Miller, C.V., Foster, G.D. and Majedi, B.F. 2003. Baseflow and stormflow metal fluxes from two small agricultural catchments in the coastal plain of Chesapeake Bay Basin, United States. Appl. Geochem. 18(4): 483-501.

Mohiuddin, K.M., Ogawa, Y., Zakir, H.M., Otomo, K. and Shikazono, N. 2011. Heavy metals contamination in the water and sediments of an urban river in a developing country. Int. J. Environ. Sci. Technol. 8(4): 723-736.

Mohiuddin, K.M., Zakir, H.M., Otomo, K., Sharmin, S. and Shikazono, N. 2010. Geochemical distribution of trace metal pollutants in water and sediments of downstream of an urban river. Int. J. Environ. Sci. Technol. 7: 17-28.

Moniruzzaman, M., Elahi, S.F. and Jahangir, M.A.A. 2009. Study on Temporal Variation of Physico-chemical Parameters of Buriganga River Water through GIS (Geographical Information System) Technology. Bangladesh J. Sci. Indus. Res. 44(3): 327-334.

Muller, G. 1969. Index of Geoaccumulation in sediments of the Rhine river. J. Geo. 2(3): 108-118. 
Persuad, D., Jaagumagi, R. and Hayton, A. 1993. Guidelines for the protection and management of aquatic sediment quality in Ontario. Ontario Ministry of the Environment, Canada. pp. 3.

Radojevic, M. and Bashkin, V.N. 1999: Practical Environmental Analysis. The Royal Society of Chemistry, Cambridge. p. 466.

Rudnick, R.L. and Gao, S. 2003. Composition of the continental crust. Treatise Geochem. 3: 1-64.

Tessier, A., Campbell, P.G.C. and Bisson, M. 1979. Sequential extraction procedure for the speciation of particulate trace metals. Anal. Chem. 51(7): 844-851.

Tomlinson, D.C., Wilson, J.G., Harris, C.R. and Jeffrey, D.W. 1980. Problems in the assessment of heavy-metal levels in estuaries and the formation of a pollution index. Helgoland Marine Res. 33: 566-575.

Turekian, K.K. and Wedepohl, K.H. 1961. Distribution of the elements in some major units of the earth's crust. Geo.I Soci. America Bullet. 72:175-192.

US EPA (U.S. Environmental Protection Agency). 1999. Screening level ecological risk assessment protocol for hazardous waste combustion facilities. Vol. 3, Appendix E: Toxicity reference values. EPA 530-D99-001C.

US EPA. 2001. Methods for Collection, Storage and Manipulation of Sediments for Chemical and Toxicological Analyses: Technical Manual. EPA-823-B-01-002. Office of Water, Washington, DC.

Wang, X.S. and Qin, Y. 2006. Spatial distribution of metals in urban topsoils of Xuzhou (China): controlling factors and environmental implications. Environ. Geol. 49: 905-914.

Zakir, H.M., Sharmin, S. and Shikazono, N. 2006. Heavy metal pollution in water and sediments of Turag river at Tongi area of Bangladesh. Int. J. Lakes Rivers. 1(1): 85-96.

Zakir, H.M., Shikazono, N. and Otomo, K. 2008. Geochemical distribution of trace metals and assessment of anthropogenic pollution in sediments of Old Nakagawa River, Tokyo, Japan. American J. Environ. Sci. 4: 654- 665. 